\title{
David Oliver: Celebrating the expert generalist
}

\author{
David Oliver consultant in geriatrics and acute general medicine
}

Berkshire

In 2011 the Royal College of General Practitioners led a commission on medical generalists. ${ }^{1}$ Definitions vary, but I like the response from the Medical Schools Council: "doctors prepared to deal with any problem presenting to them, unrestricted by particular body systems and including problems with psychological or social causes as well as physical ones." ${ }^{2}$ The Royal College of Physicians has emphasised the key role of generalist training. ${ }^{34}$

Increasingly, patients have several long term and acute conditions simultaneously. They value personalised continuity and coordination, not piecemeal care by multiple medics. ${ }^{56}$ Medical generalism in acute care- the engine room-is key to making general hospitals run and flow.

GPs are true expert generalists, dealing with a wide range of problems and presentations-nine in 10 consultations in the NHS. ${ }^{7}$ However, medical generalists also work in secondary care.

Emergency physicians see all-comers, including many patients with primary care sensitive, and multiple long term,

conditions. ${ }^{89}$ Yet they also have specific skills in the first phase of acute care, overlapping with many other medical and surgical specialties and seeing patients of all ages. Acute internal medicine physicians are also true expert generalists, albeit with specific specialist knowledge defined by the acute phase of care and the systematic organisation of "front door" services, including ambulatory care. ${ }^{10}$ Geriatricians have a role defined by complexity, frailty, multidisciplinary and cross agency working, and the age and related multiple morbidities of patients. ${ }^{11}$

Generalists are no less expert simply because their skills and value aren't defined by an organ system or procedure.

In the United Kingdom, specialists in big disciplines such as acute medicine, geriatrics, gastroenterology, respiratory and renal medicine, or endocrinology and rheumatology are mostly extensively trained and certified in general internal medicine, ${ }^{12}$ taking nine or 10 years after qualification. ${ }^{4}$ This is welcome because most acute inpatients, with a ward or clinical team defined by a primary presenting complaint, also have multiple comorbidities requiring generalist skills.
Generalists are no less expert simply because their skills and value aren't defined by an organ system or procedure

The exponential growth of evidence and interventions makes it hard to manage specific single conditions as adequately as a specialist. And if you do have, say, an acute stroke, severe asthma, or acute coronary syndrome you need prompt access to specialist care. This creates tension between specialty work and general medicine in several specialties. ${ }^{13}$

It's rare these days for people to call themselves "general physicians," even in smaller district hospitals. But job advertisements for medical generalist specialties are common, and a big general medicine contribution is often expected in others. ${ }^{12}$ This reflects the real needs of modern hospitals. We need to celebrate the expert generalists who hold such system critical roles, ensure parity of prestige, and do more to attract potential applicants.

\section{Competing interests: See www.bmj.com/about-bmj/freelance-} contributors/david-oliver.

Provenance and peer review: Commissioned; not externally peer reviewed.

1 Royal College of General Practitioners. Medical generalism: Why expertise in whole person medicine matters. Jun 2012. www.rcgp.org.uk/policy/rcgp-policy-areas/ /media/ Files/Policy/A-Z-policy/Medical-Generalism-Why_expertise_in_whole_person_medicine_ matters.ashx.

2 Medical Schools Council. Royal College of General Practitioners Commission on Generalism: response from Medical Schools Council. Jun 2011. www.medschools.ac.uk/ AboutUs/Projects/Documents/MSC\%20response\%20to\%20RCGP\%20consultation\% 20on\%20Medical\%20Generalism\%20June\%202011.pdf.

3 Thomas R. Dacre: Ignore generalist training at your peril. Health Serv J 2015 Jul 7. www. hsj.co.uk/sectors/commissioning/dacre-ignore-generalist-training-at-your-peril/5087162. fullarticle.

4 Royal College of Physicians of London. Hospital workforce: fit for the future? 28 Oct 2015. https://www.rcplondon.ac.uk/guidelines-policy/hospital-workforce-fit-future.

5 King's Fund. Continuity of care for older hospital patients: a call for action. Mar 2012. www.kingsfund.org.uk/sites/files/kf/field/field_publication_file/continuity-of-care-for-olderhospital-patients-mar-2012.pdf.

6 National Voices. A narrative for person-centred coordinated care. May 2013. www. nationalvoices.org.uk/publications/our-publications/narrative-person-centred-coordinatedcare.

7 Baird B, Charles A, Honeyman M, Maguire D, Das P; King's Fund. Understanding the pressures in general practice. 5 May 2016. www.kingsfund.org.uk/publications/pressuresin-general-practice. 
8 Cowling TE, Soljak MA, Bell D, Majeed A. Emergency hospital admissions via accident and emergency departments in England: time trend, conceptual framework and policy implications. J R Soc Med 2014;107:432-8.http://jrs.sagepub.com/content/107/11/432. fulldoi:10.1177/0141076814542669 pmid:25377736.

9 Blunt I; QualityWatch. Focus on: A\&E attendances—why are patients waiting longer? Jul 2014. www.nuffieldtrust.org.uk/sites/files/nuffield/publication/140724_focus_on_ae attendances.pdf.

10 Royal College of Physicians of London. Speciality spotlight: acute internal medicine. 3 Nov 2014. https://www.rcplondon.ac.uk/education-practice/advice/specialty-spotlightacute-internal-medicine-aim.
11 Oliver D, Burns E. Geriatric medicine and geriatricians in the UK: how they relate to acute and general internal medicine and what the future might hold? Future Hosp J 2016;1:49-54. www.bgs.org.uk/pdfs/2016_rcp_future_hospitals.pdf.

12 Royal College of Physicians. 2014-15 census (UK consultants and higher specialty trainees). 1 Feb 2016. https://www.rcplondon.ac.uk/projects/outputs/2014-15-census-ukconsultants-and-higher-specialty-trainees.

13 Firth J. The future of general medicine[abstract]. Clin Med (Lond) 2014;14:354-6.www. clinmed.rcpjournal.org/content/14/4/354doi:10.7861/clinmedicine.14-4-354 pmid:25099833.

Published by the BMJ Publishing Group Limited. For permission to use (where not already granted under a licence) please go to http://group.bmj.com/group/rights-licensing/ permissions 